\title{
CYTOTOXIC AND ANTIFUNGAL PROPERTIES OF MEDICINAL PLANTS FROM CEARÁ, BRAZIL
}

\author{
FARIA, M. H. G. ${ }^{1}$, CARVALHO, T. G. ${ }^{2}$, RABENHORST, S. H. B. ${ }^{2}$, \\ SIDRIM, J. J. C. ${ }^{2}$ and MORAES-FILHO, M. O. ${ }^{1}$ \\ ${ }^{1}$ Departamento de Fisiologia e Farmacologia \\ ${ }^{2}$ Departamento de Patologia e Medicina Legal, \\ Universidade Federal do Ceará, CEP 60431-970, Fortaleza, CE, Brazil \\ Correspondence to: Mário Henrique Girão Faria, DPML-UFC, Rua Alexandre Baraúna, s/n, Campus do Porangabussu, \\ CEP 60431-970, Fortaleza, CE, Brazil, e-mail: mariofaria@ doctor.com \\ Received October 19, 2004 - Accepted March 28, 2005 - Distributed November 1, 2006
}

(With 1 figure)

Traditional uses of plants have led to investigating their bioactive compounds through screening programs, which have resulted in the detection of a significant number of therapeutic properties. Consequently, many antitumoral drugs (Pezzuto, 1997) and antifungal agents (Rai \& Mares, 2003) currently available for clinical use are derived from plants.

Despite a less diversified flora, when compared with other regions of Brazil, Ceará presents numerous species wide used in popular medicine. The cytotoxicity and antitumoral effects, such as those produced by antifungal activity (Souza et al., 2002), of extracts from Ceará's flora has been reported (Faria et al., 2004). The purpose of this study was to evaluate antiproliferative and antifungal effects in vitro of some plant extracts made from regional flora.

Plant materials (Table 1), authenticated by Associate Professor Manoel Andrade, Departamento de Química Orgânica, Universidade Federal do Ceará, were collected from Pentecostes, Ceará, Brazil. Herbarium specimens were deposited for future reference in the Departamento de Ciências Biológicas of the Universidade Federal do Ceará.

Experiment preparation involved powdered, mainly air-dried, plant materials extracted with $50 \%$ methanol for $48 \mathrm{~h}$ at room temperature. After being placed for $2 \mathrm{~h}$ in an incubator shaker set at $200 \mathrm{rpm}$ and $35^{\circ} \mathrm{C}$, infusions were filtrated using sterile cloth sheets. This was followed by rotary evaporation under vacuum by heating in a double boiler at $40^{\circ} \mathrm{C}$ and freeze-drying overnight, after which extracts were assumed to be solventfree (Harborne, 1998). Dry extracts were then resuspended in dimethylsulfoxide (DMSO) at the desired concentrations.

Human cell line HL60 (acute promyelocytic leukemia - ATCC CCL-240) was cultivated at a concentration of $0.5 \times 10^{4}$ cells $/ 100 \mathrm{~mL}$ in 96-well plates and maintained in RPMI culture medium containing $10 \%$ bovine fetal serum and $1 \%$ penicillin-streptomycin. Soon after, they were exposed to the extracts $(0.7-100 \mu \mathrm{g} / \mathrm{ml})$ and incubated at $37{ }^{\circ} \mathrm{C}$ in $5 \% \mathrm{CO}_{2}$. After $72 \mathrm{~h}$, the medium was replaced by a $0.005 \%$ MTT (3-(4,5-dimethylthiazol-2yl)-2,5-diphenyl tetrazolium bromide) culture medium and the plates underwent 3 more hours of incubation. The reaction products were dissolved in DMSO and read on an automatic plate reader at $550 \mathrm{~nm}$ (Mosmann, 1983). The resulting measures were used as cytotoxicity parameters representing the concentration capable of inhibiting cellular growth by $50 \%\left(\mathrm{IC}_{50}\right)$.

Antifungal tests were performed using a modified disk-diffusion assay (Colombo et al., 2002). Initially, a yeast inoculum suspension of Candida krusei (ATCC 6258) adjusted to match a 0.5 McFarland density standard was prepared. A sterile cotton swab was used to apply the inoculum suspension to a $90 \mathrm{~mm}$ diameter plate containing Mueller-Hinton agar supplemented with $2 \%$ glucose and $0.5 \mu \mathrm{g} / \mathrm{mL}$ methylene blue. The plates were allowed to dry for $15 \mathrm{~min}$. Seven test disks (5 $\mathrm{mm}$ diameter) embedded in solutions 
TABLE 1

In vitro cytotoxicity $\left(\mathrm{IC}_{50}\right)$ and fungitoxicity $\left(\mathrm{MIC}_{50}\right)$ of medicinal-plant methanol extracts from Ceará, Brazil.

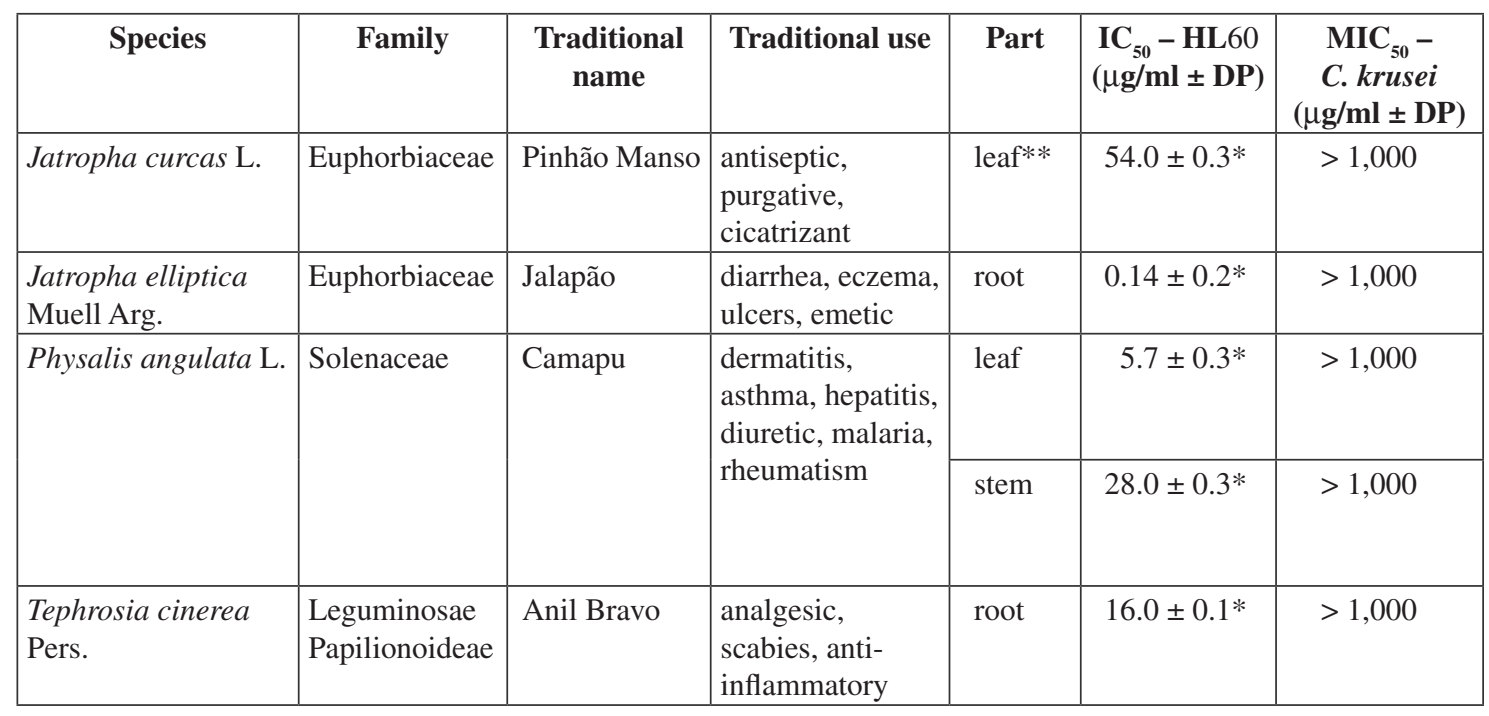

* significant cytotoxicity $(\mathrm{p}<0.05 v s$. control), ANOVA-Tukey test.

** apparent induction of cell differentiation in HL60 lineage.

of 0 (negative control) to $1,000 \mu \mathrm{g} / \mathrm{mL}$ of each extract were placed in three different plates and incubated for $24 \mathrm{~h}$ at $37{ }^{\circ} \mathrm{C}$. Three more plates (positive control) were prepared with seven disks containing 0.1 to $10 \mu \mathrm{g} / \mathrm{mL}$ amphotericin B (SIGMA Chemical Corporation, St. Louis, USA). Inhibition-zone-diameter means generated by disk diffusion tests were read manually, recorded on a logarithmical scale, plotted on a slope, and compared with a positive control slope. The mean inhibitory concentration $\left(\mathrm{MIC}_{50}\right)$ of extracts was considered as that correlating with the same result obtained using $2 \mu \mathrm{g} / \mathrm{mL}$ amphotericin B (Drago et al., 2004).

Methanol extracts of Jatropha elliptica (roots), Physalis angulata (leaves), and Tephrosia cinerea (roots) demonstrated significant cytotoxicity $\left(\mathrm{IC}_{50}<20 \mu \mathrm{g} / \mathrm{mL}\right.$ ), whereas the fungitoxicity shown by the five extracts did not rise to the same level (Table 1). However, in both cases these results are important because they indicate the presence of bioactive compounds with relative specificity against cancer cells.

Activity of the above-listed medicinal plants against tumor cells has been previously suggested by other research, which has also focused on that of antimycobacterial, molluscicidal, and trypanocidal activity (Nascimento et al., 1990). However, this is the first report on antifungal properties of these extracts. Further studies, applying the same methodology, will amplify the yeasts of these extracts to establish more precisely their potential properties as antifungicides. Another important finding in the present study was the apparent cell differentiation induced by extracts of Jatropha curcas in the HL60 cell line (Fig. 1). Recent phytochemical studies (Openshaw, 2000) establish the presence of phorbol esters (a well-know cell differentiation inducer) in this species, suggesting that these compounds might be responsible for the morphological modifications visualized.

Finally, the results of this screening of Ceará flora, which indicate that traditional medicines also serve as indicators of substances with potential for pharmaceutical production, will hopefully motivate research on compounds underlying observed activity, as well as their in vivo antitumoral potential.

\section{REFERENCES}

COLOMBO, A. L. et al., 2002, Fluconazole susceptibility of brazilian Candida isolates assessed by a disk diffusion method. Braz. J. Infect. Dis. 6(3): 118-123. 

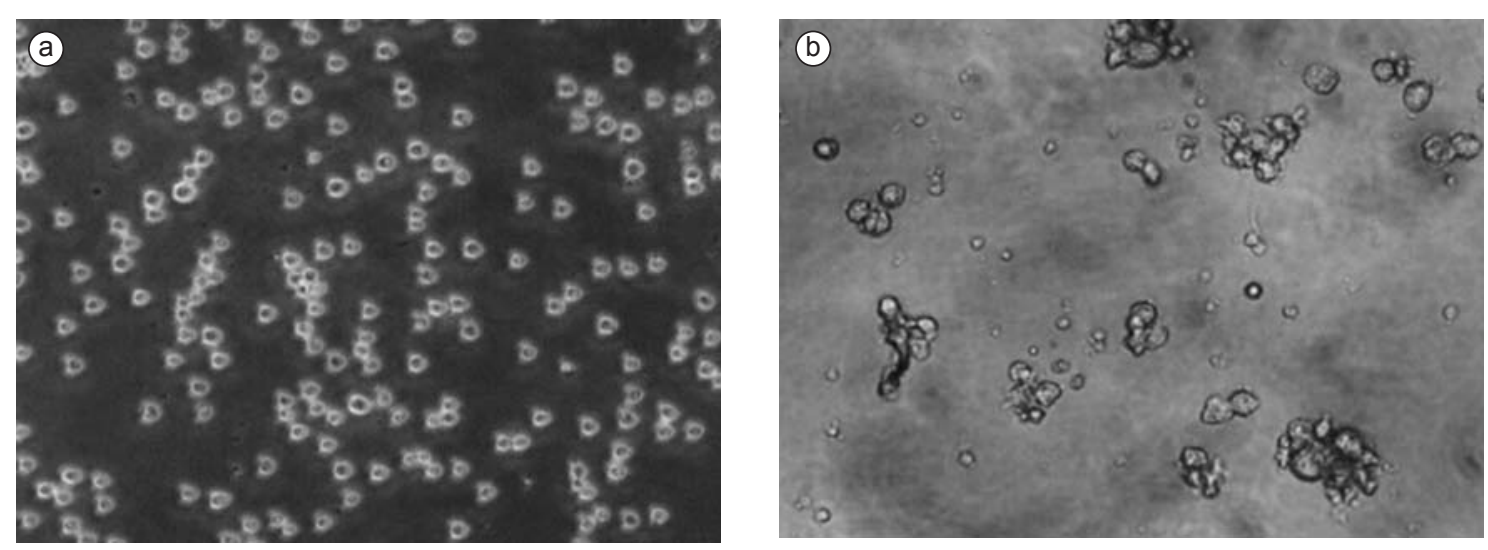

Fig. 1 - Morphological alterations observed in HL60 cell line after incubation with methanol extracts of leaves of Jatropha curcas. a) without extract (negative control); and b) with extract at $100 \mu \mathrm{g} / \mathrm{mL}(24 \mathrm{~h})$.

DRAGO, M., SCALTRITO, M. M., \& MORACE, G., 2004, In vitro activity of voriconazole and other antifungal agents against clinical isolates of Candida glabrata and Candida krusei. Eur. J. Clin. Microbiol. Infect. Dis., 23(8): 619-24.

FARIA, M. H. G. et al., 2004, Atividade citotóxica de 12 plantas medicinais do Ceará, Brasil. Rev. Bras. Farm., 83: 9-10.

HARBORNE, J. B., 1998, Phytochemical methods. 3rd. ed., Chapman and Hall, London, 1-302.

MOSMANN, T., 1983, Rapid colorimetric assay for cellular growth an survival application to proliferation and cytotoxicity assays. J. Immunol. Methods, 65: 55-63.
NASCIMENTO, S. C., CHIAPPETA, A. A. \& LIMA, R. M. O. C., 1990, Antimicrobial and cytotoxic activities in plants from Pernambuco, Brazil. Fitoterapia, 61: 353-355.

OPENSHAW, K., 2000, A review of Jatropha curcas: an oil plant of unfulfilled promise. Biomass and Bioenergy, 19: 1-15.

PEZZUTO, J. M., 1997, Plant derived anticancer agents. Biochem. Pharmacol., 53: 121-133.

RAI, M. \& MARES, D., 2003, Plant-derived antimycotics: current trends and future prospects. Food Products Press, Haworth Press, New York, 587p.

SOUZA, L. K. H. et al., 2002, Antifungal properties of brazilian cerrado plants. Braz. J. Microbiol., 33: 247-249. 
